\title{
Loss of transforming growth factor- $\beta$ type II receptor promotes metastatic head-and-neck squamous cell carcinoma
}

\author{
Shi-Long Lu, ${ }^{1}$ Heather Herrington, ${ }^{1}$ Douglas Reh, ${ }^{1}$ Stephen Weber, ${ }^{1}$ Sophia Bornstein, ${ }^{1}$ \\ Donna Wang, ${ }^{1}$ Allen G. Li, ${ }^{1,3}$ Chin-Fang Tang, ${ }^{1}$ Yasmin Siddiqui, ${ }^{1}$ Jo Nord, ${ }^{1}$ Peter Andersen, ${ }^{1}$ \\ Christopher L. Corless, ${ }^{2}$ and Xiao-Jing Wang ${ }^{1,3,4,5}$ \\ ${ }^{1}$ Department of Otolaryngology, ${ }^{2}$ Department of Pathology, ${ }^{3}$ Department of Dermatology, and ${ }^{4}$ Department of Cell and \\ Developmental Biology, OHSU Cancer Institute, Oregon Health and Science University, Portland, Oregon 97239, USA
}

\begin{abstract}
The prognosis of head-and-neck squamous cell carcinoma (HNSCC) has not been improved in the past 20 years. Validation of HNSCC biomarkers for targeted therapy has been hindered by a lack of animal models mimicking human HNSCC at both the pathological and molecular levels. Here we report that overexpression of K-ras or H-ras and loss of transforming growth factor- $\beta$ type II receptor (TGFßRII) are common events in human HNSCC. Activation of either K-ras or $\mathrm{H}$-ras in combination with TGFBRII deletion from mouse head-and-neck epithelia caused HNSCC with complete penetrance, some of which progressed to metastases. These tumors displayed pathology indistinguishable from human HNSCCs and exhibited multiple molecular alterations commonly found in human HNSCCs. Additionally, elevated endogenous TGF $\beta 1$ in these lesions contributed to inflammation and angiogenesis. Our data suggest that targeting common oncogenic pathways in tumor epithelia together with blocking the effect of TGFß1 on tumor stroma may provide a novel therapeutic strategy for HNSCC.
\end{abstract}

[Keywords: HNSCC; head-and-neck-specific knockout; metastasis; Ras; TGF $\beta R I I ;$ TGF $\beta 1$ ]

Supplemental material is available at http://www.genesdev.org.

Received January 25, 2006; revised version accepted March 17, 2006.

Head-and-neck cancer refers to cancers that develop from the nasal and oral cavities, the throat, and the upper esophagus. More than $90 \%$ of head-and-neck cancer cases are head-and-neck squamous cell carcinomas (HNSCCs) (Forastiere et al. 2003). HNSCCs represent the sixth most common cancer in the United States (Jemal et al. 2004). Unlike other cancers in which lethality is associated with metastasis, primary HNSCCs can cause death as a result of internal bleeding, airway obstruction, and malnutrition related to difficulty with food intake. Among the multiple common genetic alterations identified in HNSCCs, alterations that specifically play a role in initiation and/or promotion in HNSCC have yet to be defined. K-ras or H-ras gene mutation, a common initiation event in human cancers (Hanahan and Weinberg 2000), occurs in $>50 \%$ of oral cancer cases in south Asian populations (Saranath et al. 1991), but varies from $5 \%$ to $20 \%$ of oral cancer cases in Western countries (Anderson et al. 1994; Hardisson 2003; Weber et al. 2003). However, increased wild-type

${ }^{5}$ Corresponding author.

E-MAIL wangxiao@ohsu.edu; FAX (503) 402-2817.

Article and publication are at http://www.genesdev.org/cgi/doi/10.1101/ gad.1413306.
K-ras or H-ras protein levels occur at a much higher rate than ras mutation in HNSCC cases in the United States (McDonald et al. 1994; Hoa et al. 2002). Similar to mutant ras, wild-type ras overexpression is sufficient to induce hyperproliferation of HNSCC cells (Hoa et al. 2002). In mice, K-ras activation initiates benign papilloma formation in head-and-neck epithelia, but is insufficient to induce invasive HNSCCs (Caulin et al. 2004; Vitale-Cross et al. 2004), even though one study observed skin SCC formation (Vitale-Cross et al. 2004).

Among potential tumor promotion events for HNSCC, somatic mutations in the gene encoding transforming growth factor- $\beta$ type II receptor (TGF $\beta R I I)$ and reduction of TGF $\beta$ RII protein have been identified in human HNSCC samples (Garrigue-Antar et al. 1995; Wang et al. 1997; Fukai et al. 2003). Although the role of TGFßRII in SCC development has been extensively studied (for reviews, see Reiss 1999; Wang 2001; Prime et al. 2004), the role of TGFßRII in HNSCC pathogenesis has yet to be determined. It is commonly accepted that TGF $\beta$-mediated tumor-suppressive effects require functional TGF $\beta$ RII. However, TGF $\beta$ also promotes tumor invasion at later stages of carcinogenesis (Reiss 1999; Wang 2001; Prime et al. 2004), and the results related to TGF $\beta$ RII loss in TGF $\beta$-associated tumor promotion are 
conflicting in both clinical studies (Tateishi et al. 2000; Watanabe et al. 2001; Fukai et al. 2003) and experimental systems (Yang et al. 2002; Siegel et al. 2003; Forrester et al. 2005; Han et al. 2005). In the current study, we focus on assessing the role and mechanisms of TGF $\beta$ RII loss in HNSCC development and progression.

\section{Results}

Overexpression of ras and loss of TGFBRII expression are common events in human HNSCCs

Previously, overexpression of Ras protein in human HNSCC has been reported to reach $\sim 70 \%$ of cases for H-ras, and $45 \%$ of cases for K-ras (McDonald et al. 1994). To determine whether ras is activated at the transcriptional level in HNSCC, we examined $\mathrm{K}$-ras and $\mathrm{H}$-ras transcripts in 32 pairs of human HNSCCs and adjacent tissues. Oropharyngeal samples from sleep apnea patients were included as normal controls. In comparison with the average $\mathrm{K}$-ras or $\mathrm{H}$-ras expression level in normal tissue, 18/32 (56\%) HNSCC samples and 10/32 $(31 \%)$ adjacent tissue samples exhibited twofold to $14-$ fold greater levels of K-ras mRNA, and 12/32 (38\%) HNSCC samples and 15/32 (47\%) adjacent tissue samples exhibited twofold to 25 -fold greater levels of $H$ ras mRNA (Fig. 1A,B). Sequencing analyses revealed that three $(9 \%)$ HNSCC samples without K-ras overexpression possessed a glycine (G)-to-aspartic acid (D) mutation at codon 12 of the $K$-ras gene, a rate that is similar to previous reports (Hardisson 2003; Weber et al. 2003). In contrast to oral cancer cases in South Asia, in which the frequency of $H$-ras mutations exceeds that of $K$-ras mutations (Saranath et al. 1991), no mutation of $H$-ras was found in these HNSCC samples. This result suggests that exposure to different types of oral carcinogens could affect specific molecular alterations in HNSCCs. Nevertheless, $81 \%$ of the human HNSCC samples we analyzed exhibited either overexpression of wild-type K-ras or $\mathrm{H}$ ras or, albeit less frequently, mutation of K-ras. Immunohistochemistry to detect Ras protein in these samples revealed that Ras protein was barely detectable in normal oropharyngeal epithelia of sleep apnea patients, but stained strongly in the mucosa adjacent to HNSCCs and HNSCC lesions in which elevated transcripts were detected (Supplementary Fig. 1). The overall cases of Raspositive staining correlated with the increased mRNA levels. These data suggest that ras overexpression in human HNSCCs occurred predominantly at the transcriptional level.

Previous reports indicated that loss of TGF $\beta$ RII protein is more frequent than disruption at the genetic level in HNSCC (Garrigue-Antar et al. 1995; Wang et al. 1997; Fukai et al. 2003). To determine whether TGFßRII loss occurs mainly at the pre- or post-translational level, we examined TGFßRII transcripts in human HNSCCs and adjacent tissues. The average expression level in the normal control samples was arbitrarily set as $100 \%$. The average mRNA level of TGFBRII in the normal control group was $100 \% \pm 29 \%$ (Fig. 1C). The average mRNA level of TGFBRII in tissue samples adjacent to HNSCCs

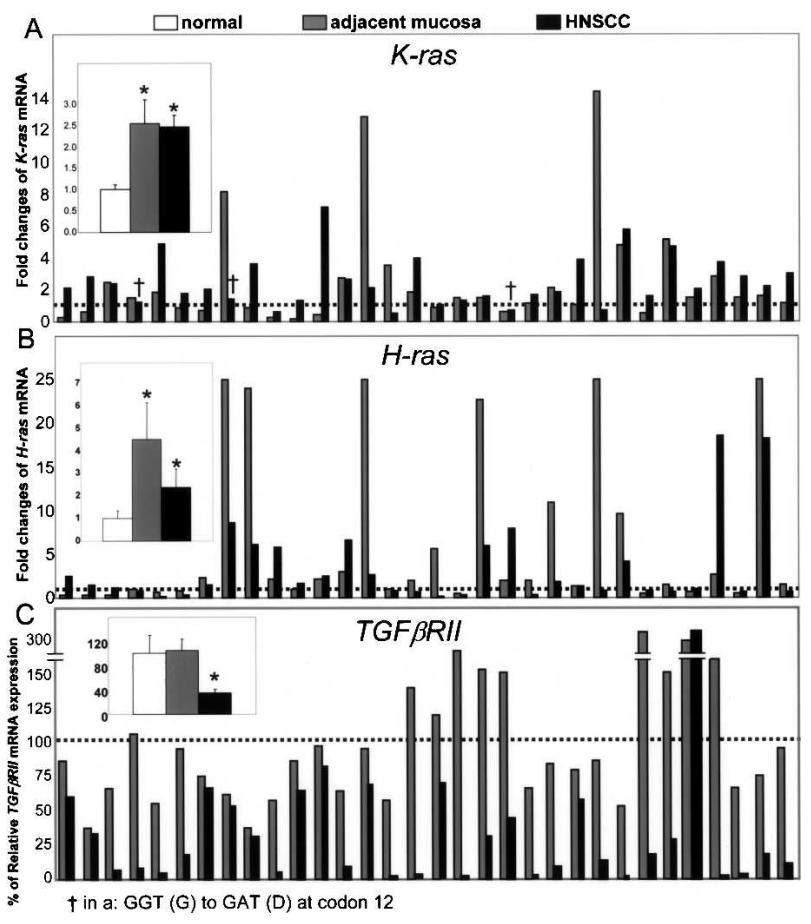

Figure 1. Ras overexpression and mutation, and reduction/loss of TGF $\beta I I$ expression in human HNSCC samples examined by qRT-PCR. Each pair of bars in the main graph represents the fold change of tumor and adjacent mucosa from a single case relative to a normal control group. The case ID and numbers were identical and in the same order in all three panels. The average fold change for each tissue type is shown in the inset. Seven normal oropharyngeal samples from sleep apnea patients and 32 pairs of HNSCC and adjacent tissue samples were examined. The dotted horizontal line in each of the main graphs represents the average expression level of each molecule from the normal control group. (A) Expression levels of $\mathrm{K}$-ras. The average $K$-ras mRNA levels in HNSCC samples and adjacent tissue samples are presented in the inset. $(\dagger)$ Tumors with a G-to-D mutation at codon 12 of the $K$-ras gene. $(B)$ Expression levels of $H$-ras. The average $H$-ras mRNA levels in HNSCCs and adjacent tissue samples are presented in the inset. $(C)$ TGF $\beta R I I$ mRNA levels in human HNSCC samples. The average levels of TGFßRII mRNA in HNSCC and adjacent tissue samples are presented in the inset. $\left(^{*}\right) p<0.01$ in comparison with normal control.

was $108 \% \pm 14 \%$, which is similar to the levels in normal controls (Fig. 1C). However, the average level of TGFßRII mRNA in HNSCC samples was $36 \% \pm 11 \%$, which was significantly lower than that in the adjacent mucosa or normal controls $(p<0.01)$ (Fig. 1C). Among 32 pairs of HNSCC samples, $22(69 \%)$ HNSCC samples and two $(6.3 \%)$ adjacent tissue samples exhibited a $>50 \%$ decrease in TGFBRII mRNA level in comparison with the average expression level of normal tissue samples (Fig. $1 C)$. We then performed TGFßRII immunohistochemistry on these samples. TGF $\beta$ RII staining exhibited a similar intensity in both the normal oropharyngeal epithelia of sleep apnea patients and the mucosa adjacent to HNSCCs (Supplementary Fig. 1), but was significantly reduced or lost in HNSCC cells (Supplementary Fig. 1). 
The overall TGFßRII loss observed using immunohistochemistry correlated with the reduced mRNA levels. These data suggest that reduction or loss of TGFßRII expression in human HNSCCs occurred predominantly at the pretranslational level. In total, 20 out of 32 HNSCC samples $(63 \%)$ exhibited concurrent ras overexpression/mutation and TGF $\beta R I I$ loss.

\section{Head-and-neck epithelia with TGFßRII deletion together with a K-ras or H-ras mutation developed SCCs in mice}

To further define the role of TGFßRII loss in HNSCC development, we developed an inducible head-and-neckspecific knockout system. The system consists of two mouse lines, K5.CrePR1 mice (Arin et al. 2001) and $T G F \beta R I I^{f / f}$ mice (Forrester et al. 2005). In the K5.CrePR1 line, the Cre recombinase is fused to a truncated human progesterone receptor $(\Delta \mathrm{PR})$, which can be activated by RU486. This fusion protein is driven by the keratin 5 (K5) promoter, which targets gene expression specifically to the epidermis and head-and-neck epithelia, which include the lining of the oral cavity, tongue, esophagus, and forestomach. (Lu et al. 2004). In the TGF $3 I^{f / f}$ line, exon 2 of the TGFBRII gene is floxed (Forrester et al. 2005). After crossing the K5.CrePR1 line with the $T G F \beta R I I^{f / f}$ line, TGF $R$ RII deletion from head-and-neck epithelia can be achieved by application of RU486 specifically to these areas in K5.CrePR1/TGF $R$ RIf $f^{f /}$ bigenic mice (Supplementary Fig. 2). To ablate TGFBRII in headand-neck epithelia, 4-wk-old mice were genotyped, and RU486 (20 $\mu \mathrm{g} / \mathrm{mouse}$ ) was applied to the oral cavity daily for $5 \mathrm{~d}$. Since the $K 5$ promoter targets Cre expression in head-and-neck epithelial stem cells (Caulin et al. 2004), once RU486-induced excision occurs, the regenerated stratified epithelia from mutant stem cells will harbor the TGFBRII deletion for life. Therefore, repeated RU486 application is not necessary after the gene has been deleted in stem cells (Caulin et al. 2004). Since the rate of renewal of the murine stratified epithelia from the stem cells is $\sim 8-10 \mathrm{~d}$ (Potten et al. 1987), we euthanized mice $10 \mathrm{~d}$ after the final RU486 treatment and extracted DNA to examine TGFBRII deletion from head-and-neck tissues; i.e., the buccal tissue, tongue, esophagus, and forestomach. The recombinant TGF $R$ RII allele lacking exon 2 (Supplementary Fig. 2) was detected in the head-andneck tissue samples of K5.CrePR1/TGF $R$ RII ${ }^{/ f}$ mice treated with RU486 (hereafter referred to as TGFßRII ${ }^{-/-}$ mice), but not in RU486-treated K5.CrePR1 or TGF $\beta R I I^{f / f}$ mice (hereafter referred to as TGF $R I^{+/+}$ mice). In addition, TGFBRII deletion did not occur in other organs, such as the heart, lung, liver, or spleen, of TGF $\beta R I I^{-/-}$mice (Supplementary Fig. 2B). TGF $R$ RII mRNA was also examined by quantitative RT-PCR (qRT-PCR). The expression levels of TGF $\beta R I I$ in TGF $\beta R I I^{+/+}$mice were normalized as $100 \% \pm 15 \%$ in the buccal tissue, $100 \% \pm 6 \%$ in the tongue, and $100 \% \pm 19 \%$ in the esophagus. The levels were significantly reduced to $12 \% \pm 15 \%$ in the buccal tissue, $18 \% \pm 6 \%$ in the tongue, and $9 \% \pm 8 \%$ in the esophagus of $T G F \beta R I I^{-/-}$mice (Fig. 2A). The low level of TGFBRII expression in $T G F \beta R I I^{-1-}$ tissue was presumably residual expression from the cells in the stroma where TGFBRII deletion did not occur. Furthermore, TGFßRII protein was undetectable in the buccal tissue or tongue of $T G F \beta R I I^{-/-}$mice in comparison with those of TGF $\beta R I I^{+/+}$mice (Fig. 2B), suggesting that the level of TGFßRII protein in the stroma was too low to be de-
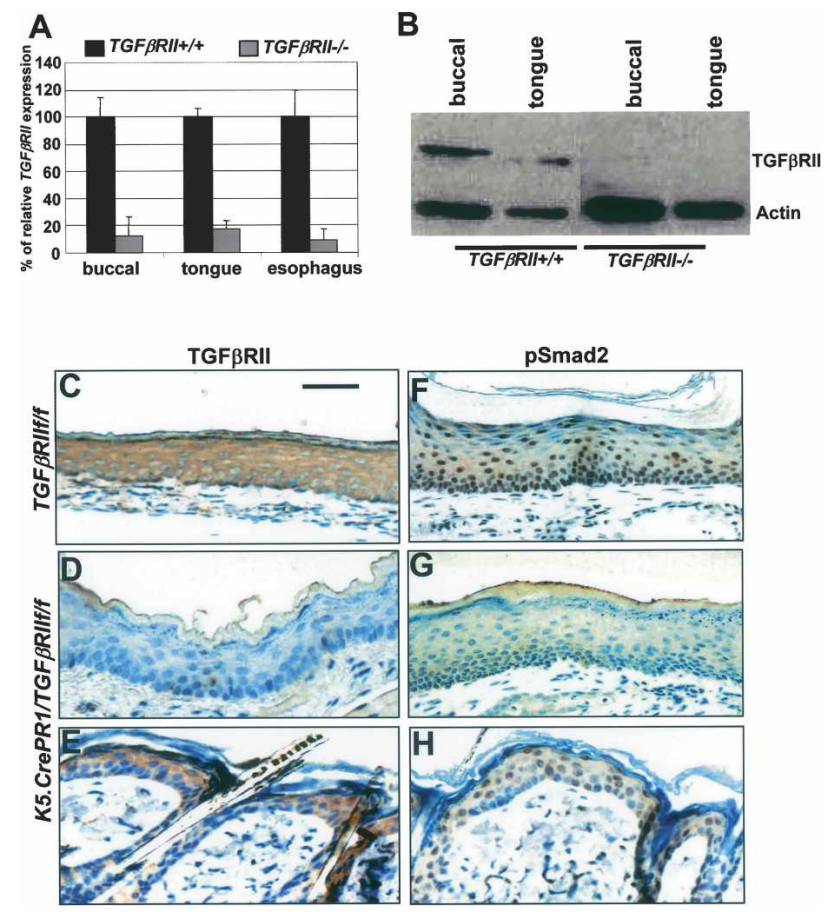

Figure 2. TGFBRII deletion in head-and-neck epithelia abrogated Smad2 phosphorylation. (A) Relative expression levels of TGF $\beta R I I$ transcripts examined by qRT-PCR. The average expression levels from four representative samples in each group are presented. The average expression level of TGF $\beta R I I$ in the TGF $\beta R I I^{+/+}$samples of each group was arbitrarily set as $100 \%$. (B) Western analysis of TGFßRII protein. Note that TGFßRII protein was detectable in the buccal mucosa and tongue of TGF $\beta R I I^{+/+}$mice, but was undetectable in those of TGF $\beta R I I^{-/-}$ mice. The membrane was stripped and reprobed with an antiactin antibody as a loading control. $(\mathrm{C}-\mathrm{H})$ Immunohistochemistry staining of TGFßRII $(C-E)$ and pSmad2 $(F-H)$ in mouse buccal tissue and the skin, 1 yr after the last oral RU486 application. $(C)$ Note that TGF $\beta$ RII protein was detected in buccal epithelia of a $T G F \beta R I I^{+/+}$(i.e., $T G F \beta R I I^{f / f}$ ) mouse orally treated with RU486. (D) TGFßRII was specifically ablated in the buccal epithelium of a K5.CrePR1/TGF $\beta$ RII $I^{f / f}$ mouse treated orally with RU486. (E) The epidermis and hair follicles of a K5.CrePR1/TGFßRII f/f mouse treated orally with RU486 exhibited a TGF $\beta$ RII staining pattern similar to nontransgenic mouse skin (not shown). Nuclear staining of pSmad2 was detected in some cells in the buccal epithelium of a TGF $R$ RIf $f^{f / f}$ mouse orally treated with RU486 $(F)$, but was absent in the buccal epithelial cells of the K5.CrePR1/TGF $\beta R I I^{f / f}$ mouse orally treated with RU486 $(G)$. $(H)$ The epidermis and hair follicles of the K5.CrePR1/TGF $\beta R I I^{f / f}$ mouse orally treated with RU486 exhibited the number of positive nuclear pSmad2 cells similar to that in nontransgenic epidermis and hair follicles (not shown). Bar, $40 \mu \mathrm{m}$. 
tected. However, no significant pathological changes in the head-and-neck epithelia of TGFBRII-/- mice were observed in comparison with that of $T G F \beta R I I^{+/+}$mice after $1 \mathrm{yr}$ of observation. Immunostaining confirmed that TGFBRII was prominently expressed in head-and-neck epithelia of TGFBRII ${ }^{+/+}$mice (Fig. 2C), but was persistently ablated in the epithelial compartment of headand-neck tissue of TGFBRII ${ }^{-/-}$mice at all time points examined up to 1 yr of age (Fig. 2D). As a result of epithelial TGFßRII deletion, Smad2 phosphorylation, a marker for activated TGF $\beta$ signaling, was lost in headand-neck epithelia of $T G F \beta R I I^{-/-}$mice (Fig. 2G) in comparison with those of TGF $3 R_{I^{+/+}}$mice (Fig. 2F). In contrast, the skin epidermis and hair follicles of the same mice with head-and-neck TGFBRII deletion retained a normal staining pattern for TGF $\beta$ RII (Fig. 2E) and phosphorylated Smad2 (Fig. 2H) in the epidermis and hair follicles, suggesting that there was minimal, if any, systemic gene deletion effect of RU486. The lack of spontaneous tumor formation in TGFßRII-/- epithelia, together with the results from human HNSCCs, in which TGFßRII loss occurred only in HNSCCs but not in preneoplastic lesions, suggests that loss of TGF $\beta$ RII is not an initiation event in HNSCC development.

We then bred the conditional TGFBRII-/- mice with $L S L-K-$ ras $^{G 12 D /+}$ mice in which a codon 12 G-to-D mutation can be induced upon Cre activation (Jackson et al. 2001). Oral RU486 treatment in these compound mice concomitantly induced one allele of the K-ras ${ }^{12 D}$ mutation and homozygous TGFBRII deletion in head-andneck epithelia (referred to as K-ras ${ }^{12 D /+} / T G F \beta R I I^{-/-}$). As previously observed (Caulin et al. 2004), in the TGF $B R I^{+/+}$background, K-ras $^{12 D /+}$ head-and-neck epithelia began developing benign papillomas $3 \mathrm{wk}$ after the final RU486 treatment (data not shown). Although these tumors remained benign, they exceeded acceptable sizes within $3 \mathrm{mo}$, and the mice were euthanized. In contrast, K-ras ${ }^{12 D /+} / T G F \beta R I I^{-/-}$mice did not develop typical papillomas, but began developing SCCs $5 \mathrm{wk}$ after the final RU486 treatment (Fig. 3A). The aggressive growth of primary tumors compromised the mice within 3-4 wk after initial SCC formation, which prevented us from assessing whether these tumors would progress to metastasis. To circumvent this problem, we introduced an H-ras mutation by applying one subcarcinogenic dose $(20 \mu \mathrm{g}$ per mouse) of 7, 12-dimethylbenz[a]anthracene (DMBA) to the mouse oral cavity. Unlike $K-\mathrm{ras}^{12 D /+}$ mice, in which mutant $K$-ras is activated in all head-and-neck epithelial cells, DMBA induces $H$-ras mutations in sporadic cells (initiated cells) that require clonal expansion for tumor formation. DMBA-initiated TGFBRII ${ }^{-/-}$mice began developing head-and-neck tumors at $11 \mathrm{wk}$ of age and reached $100 \%$ incidence by 41 wk of age (Fig. 3E). Tumors in DMBA-initiated TGFBRII ${ }^{-/-}$mice arose mostly from the oral cavity (similar to Fig. 1A), tongue (Fig. 3B,F), esophagus, and forestomach (Fig. 3C,F), which are lined with stratified epithelium similar to that of the upper esophagus in humans. Furthermore, $35 \%$ of the DMBA-initiated TGF $\beta R I I^{-/-}$mice developed jugular lymph node metastases by 20-39 wk of age (Fig. 3D,F), a
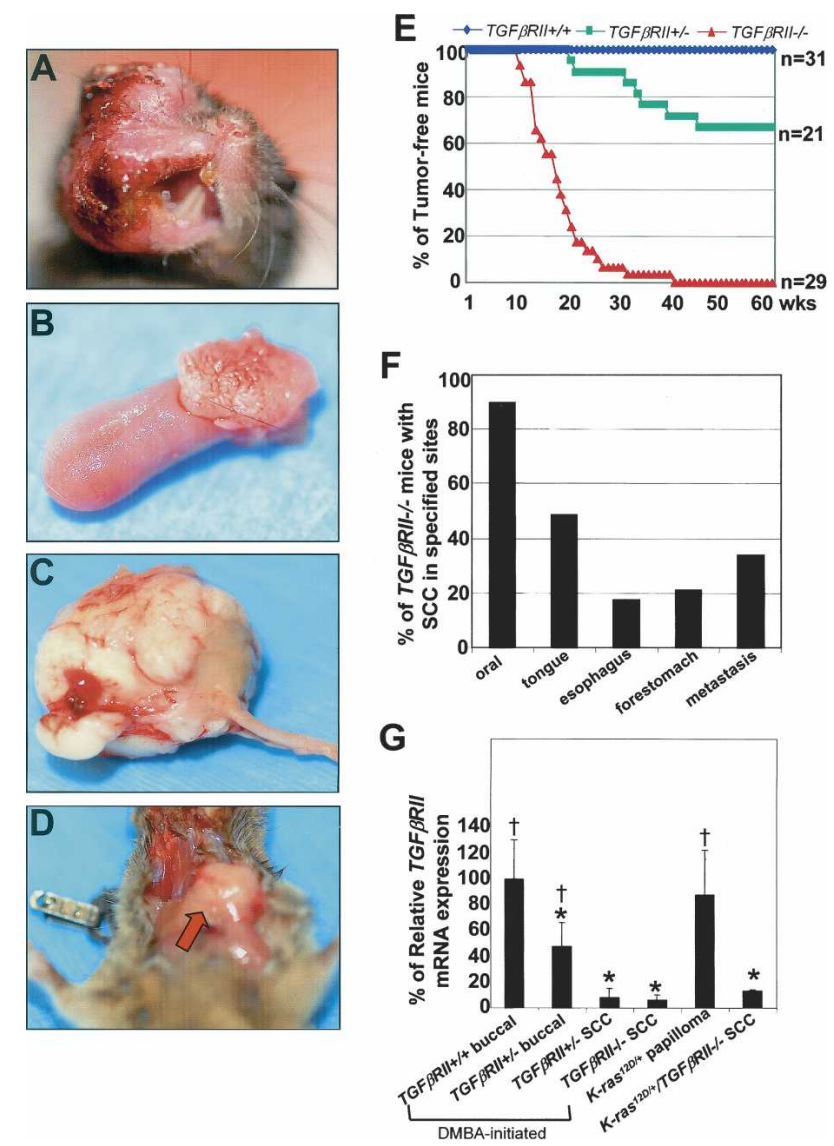

Figure 3. $K$-ras ${ }^{12 D /+} / \mathrm{TGF} R I^{-/-}$mice or DMBA-initiated $T G F \beta R I I^{-1-}$ mice developed HNSCCs. $(A-D)$ Gross appearance of SCCs occurring in the oral cavity of a $\mathrm{K}$-ras ${ }^{12 D /+} / \mathrm{TGF} \mathrm{RII} I^{-/-}$ mouse $(A)$ and the tongue $(B)$, lower esophagus and forestomach $(C)$, and jugular lymph node metastasis $(D)$ from DMBAinitiated TGF $R R^{-1-}$ mice. Oral lesions in DMBA-initiated $T G F \beta R I I^{-1-}$ mice were similar to $A$. (E) Kinetics of tumor formation in DMBA-initiated TGF $R R I^{-/-}$mice. Tumor formation was assessed by either gross appearance (oral or tongue) or by necropsy (esophagus or forestomach). Data points represent the percentage of tumor-free mice calculated against the total number of mice in each group. (F) Percentage of TGF $R$ RII $I^{-/-}$mice with HNSCC in specified sites as determined by histological analyses. (G) Levels of TGF $\beta R I I$ transcripts in tumor samples. Preneoplastic head-and-neck lesions were dissected at 4 wk after DMBA initiation. $\left(^{*}\right) p<0.01$ in comparison with DMBAinitiated TGF $R R^{+/+}$buccal tissue; $(\dagger) p<0.01$ in comparison with DMBA-initiated TGF $\beta R I I^{-/-}$SCCs. The remaining TGF $\beta R I I$ mRNA in TGFBRII $I^{+-}$or TGFBRII $I^{-/}$SCC samples was most likely attributed to stromal cell expression.

common metastatic site for human HNSCCs. We examined ras mutations in these tumors. Among 15 tumors examined, 13 exhibited an A-to-T substitution at codon 61 of the H-ras gene, and two exhibited an A-to-T substitution at codon 61 of the K-ras gene, which results in a glutamine-to-leucine substitution in either of the genes (data not shown), and represents a hotspot mutation for human cancer (Saranath et al. 1991). None of the DMBA-initiated TGF $\beta R I I^{+/+}$mice developed tumors during a 60 -wk observation (Fig. 1E). Additionally, no 
tumors developed in the skin epidermis of DMBA-initi-

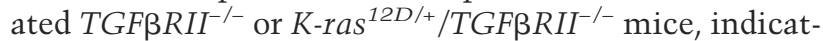
ing that the inducible head-and-neck-specific knockout system was tightly regulated. About $33 \%$ of mice with heterozygous TGFßRII deletion in head-and-neck epi-

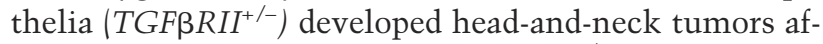
ter DMBA initiation (Fig. 3E). TGF $R I^{+/-}$tumors exhibited TGFBRII mRNA levels similar to those in TGF $\beta R I I^{-1-}$ tumors; i.e., $8 \% \pm 6 \%$ in the TGF $\beta R I I^{+/-}$tumors $(n=6), 6 \% \pm 4 \%$ in DMBA-initiated TGFBRII ${ }^{-/-}$ tumors $(n=6)$, and $13 \% \pm 2 \%$ in $\mathrm{K}_{-\mathrm{ras}^{12 D /+}} / \mathrm{TGF}^{12} \mathrm{III}^{-/-}$ tumors $(n=6)$ in comparison with $100 \% \pm 31 \%$ in DMBA-initiated TGF $R I^{+/+}$buccal tissue $(n=4)$, $49 \% \pm 18 \%$ in DMBA-initiated TGFBRII ${ }^{+/}$buccal tissue $(n=5)$, or $88 \% \pm 35 \%$ in $K$-ras ${ }^{12 D /+}$ papillomas $(n=6)$ (Fig. 3G). This result suggests that TGF $R I I$ expression from the remaining allele in TGF $\beta R I I^{+/-}$tumor epithelia was spontaneously lost or repressed. Almost all of the tumor-bearing mice were compromised by the aggressive growth of the primary tumors, which caused internal bleeding, difficulty with food intake, and airway obstruction. These are common causes of death in human HNSCC patients who do not have an option for surgery.

In contrast to $K-\mathrm{ras}^{12 D /+}$ papillomas, early lesions in $\mathrm{K}_{\text {-ras }}{ }^{12 D /+} / \mathrm{TGF} \mathrm{RII}^{-/-}$or DMBA-initiated TGF $\mathrm{TII} I^{-/-}$ epithelia progressed from hyperplasia (Fig. 4B) to dysplasia (Fig. 4C). Once tumors developed from these early lesions, they were exclusively SCCs. Along with tumor progression, the lesions progressed through the stages of well, moderately, and poorly differentiated SCCs (Fig. 4D-L). Histopathology of these tumors revealed enlarged nuclei with prominent nucleoli and a high mitotic index (Fig. 4G) and invasion of local tissues such as muscle (Fig. 4H), peripheral nerve (data not shown), and lymph nodes (Fig. 4I). Tumors exhibited patchy or complete loss of keratin K13 expression (Fig. 4J), a marker for head-andneck epithelia but not normal or hyperplastic epidermis (Bloor et al. 1998), and positive staining for K18 (Fig. 4K), a marker for late-stage SCC (Ogden et al. 1993). In metastatic lesions, keratin pearls were evident (Fig. 4I), and tumor cells exhibited patchy K13 expression (Fig. 4L).

\section{TGFBRII deletion allowed accumulation of molecular alterations commonly observed in human HNSCCs}

It is believed that, similar to other cancer types, accumulation of genetic alterations for HNSCC formation begins with "field cancerization"; i.e., the grossly normal-appearing mucosa often harbors genetic alterations that predispose cells toward malignancy (Mao et al. 2004). Therefore, we examined molecular alterations in preneoplastic tissues and tumor lesions in these mouse models. Since K-ras ${ }^{12 D /+}$ papillomas or K-ras ${ }^{12 D /+} /$ TGF $\beta R I I^{-/-}$SCCs developed tumors almost immediately after the mutant $\mathrm{K}$-ras ${ }^{12 D /+}$ stem cells repopulated the entire epithelia, it was difficult to dissect preneoplastic lesions from these mice. Therefore, data representing preneoplastic lesions are from DMBA-initiated tissues, 4 wk after DMBA initiation. At this stage, hematoxylin and eosin $(H \& E)$ sections did not reveal a significant difference between TGF $\beta R I I^{+/+}$and TGF $R I^{I^{-/}}$tissues. Additionally, hyperplastic lesions at later time points or
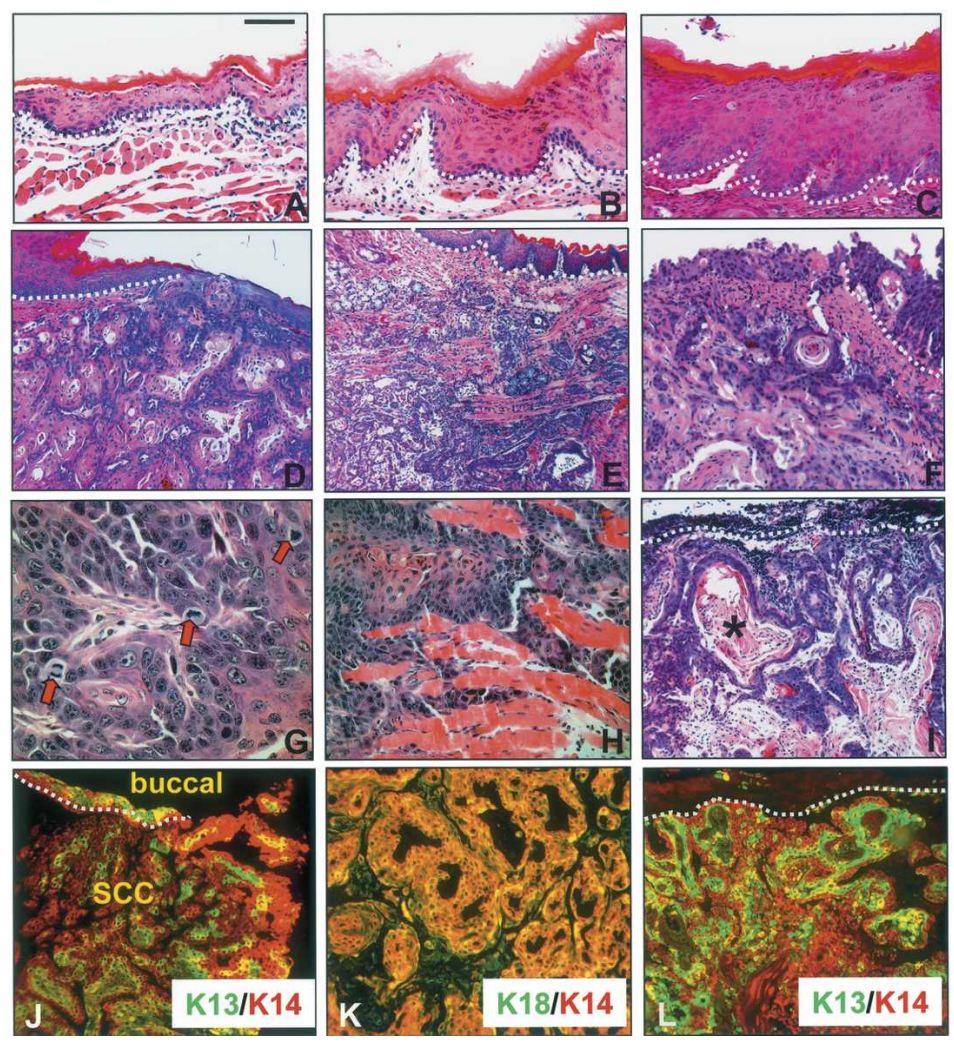

Figure 4. Tumor pathology. Buccal tissue from $T G F \beta R I I^{+/+}(A)$ and $T G F \beta R I I^{-/-}(B)$ mice 6 wk after DMBA initiation. K-ras ${ }^{12 D /+} / T_{G F} R I^{-/-}$mice developed hyperplastic lesions similar to those shown in $B$ $1-3$ wk after concurrent induction of $\mathrm{K}$-ras ${ }^{12 D /+}$ activation and TGFBRII deletion (not shown). (C) A dysplastic buccal lesion developed in a $\mathrm{K}$-ras ${ }^{12 D /+} / T G F \beta R I I^{-/-}$ mouse 5 wk after $\mathrm{K}$-ras ${ }^{12 D /+}$ induction and TGF $\beta R I I$ deletion. $(D-I) \mathrm{H} \& \mathrm{E}$ tumor sections of a buccal SCC in a $\mathrm{K}_{\text {-ras }}{ }^{12 D /+} / \mathrm{TGF} \beta R I I^{-/-}$mouse $(D)$, and SCCs derived from the tongue $(E)$, forestomach $(F)$, and lymph node metastasis $(I)$ of DMBA-initiated TGF $R R I I^{-/-}$mice. K-ras ${ }^{12 D /+} / T G F \beta R I I^{-/-}$or DMBA-initiated TGFßRII $I^{-/-}$ primary SCCs exhibited identical pathology and keratin expression patterns. High magnification shows SCC cells with enlarged nuclei, increased mitosis $(G$, arrows), and muscle invasion $(H)$. Staining of keratin markers $\mathrm{K} 13(J, L)$ or K18 $(K)$ with counterstain K14 (J-L) in primary $(J, K)$ and metastatic $(L)$ HNSCCs. The dotted lines in $A-F$ and $J$ delineate the adjacent epithelial compartment. Dotted lines in $I$ and $L$ delineate the boundary between metastatic tumor cells and lymph node tissue. The asterisk in $I$ highlights keratin pearl. Bars: $A-C, H, 20 \mu \mathrm{m} ; D, F, I-L, 40 \mu \mathrm{m} ; E, 100 \mu \mathrm{m} ; G, 10 \mu \mathrm{m}$. 
tissues adjacent to SCC were also analyzed, and the alterations were found to be similar to those in the above preneoplastic lesions (data not shown).

To examine whether TGF $\beta$ RII deletion abrogated TGF $\beta$-mediated growth arrest and thus promoted initiated cancer cells, we examined expression levels of classic TGF $\beta$ target genes that mediate TGF $\beta$-induced growth arrest. These genes include cyclin-dependent kinase inhibitors $p 15$ and $p 21$, which are normally induced by TGF $\beta$, and $c$-myc, which is suppressed by TGF $\beta$ (Massague 2004). DMBA-initiated TGF $R I^{-/-}$preneoplastic buccal tissues and tumors as well as $\mathrm{K}_{-} \mathrm{ras}^{12 \mathrm{D} / \mathrm{H}}$ / TGF $R I^{-/-}$tumors exhibited significant reduction in $p 15$ and $p 21$ expression and elevated $c$-myc expression in comparison with DMBA-initiated TGFßRII $I^{++}$buccal tissues or $\mathrm{K}_{\text {-ras }}{ }^{12 D /+}$ papillomas (Fig. 5A,B). In comparison with DMBA-initiated TGFBRII ${ }^{+/+}$buccal tissues, expression levels of $p 15$ were not significantly altered in K-ras ${ }^{12 D /+}$ papillomas $(128 \% \pm 35 \%)$, but were reduced to $41 \% \pm 26 \%$ in DMBA-initiated TGFBRII ${ }^{-/}$preneoplastic buccal tissue, $46 \% \pm 27 \%$ in DMBA-initiated SCC, and $38 \% \pm 20 \%$ in $\mathrm{K}_{-\mathrm{ras}^{12 D /+} / \mathrm{TGF}^{12} \mathrm{RII} I^{-/} \text {SCCs }}$ (Fig. 5A). Similarly, in comparison with DMBA-initiated
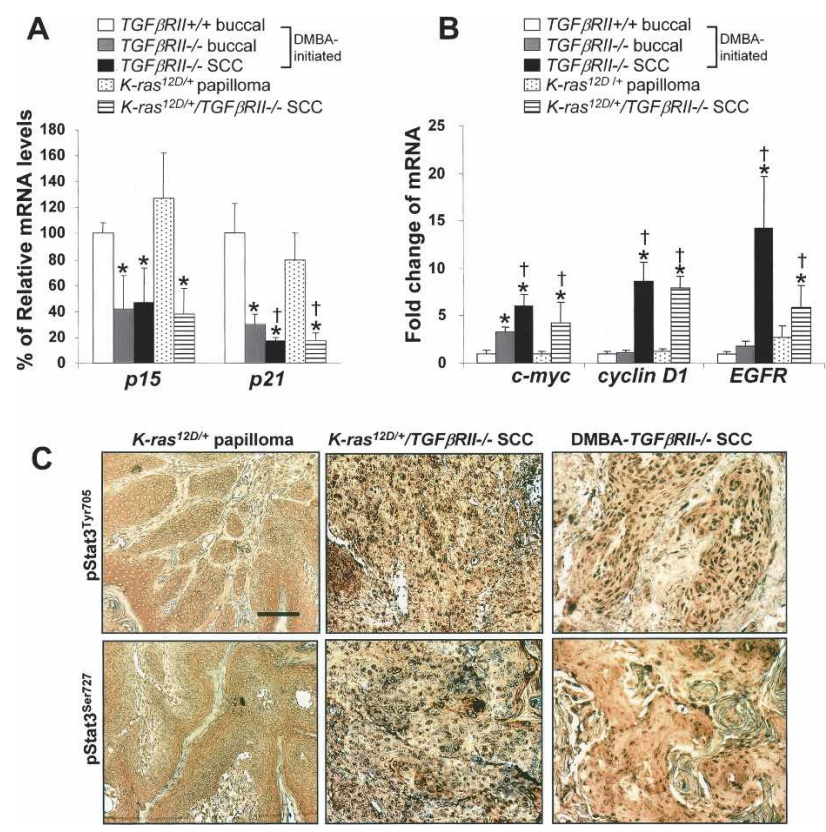

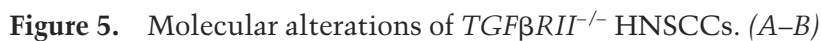
Relative expression levels of individual genes in preneoplastic and tumor lesions. Preneoplastic head-and-neck lesions were dissected at $4 \mathrm{wk}$ after DMBA initiation. Each group contained six tumor samples for qRT-PCR analyses. $\left(^{*}\right) p<0.01$ in comparison with DMBA-initiated TGF $R I I^{+/+}$buccal tissue; $(\dagger)$ $p<0.01$ in comparison with DMBA-initiated TGF $R I^{-/-}$buccal tissue. (C) Immunohistochemistry staining of phosphorylated Stat3 (pStat3) in K-ras ${ }^{12 D /+}$ papillomas and $\mathrm{K}_{\text {-ras }}{ }^{12 D /+} / \mathrm{TGF} \mathrm{RII} \mathrm{I}^{-/-}$ and DMBA-initiated TGFBRII-/- SCCs using pStat $3^{\text {Tyr } 705}$ and pStat $3^{\mathrm{Ser} 727}$ antibodies. Note that pStat 3 was not detected in K-ras ${ }^{12 D /+}$ papillomas (C) or DMBA-initiated TGF $R R I^{+/+}$or TGF $\beta R I I^{-/-}$buccal tissues (not shown), but was detected in the nucleus of TGF $\beta R I I^{-/-}$SCC tumor cells. Bar, $40 \mu \mathrm{m}$.
TGF $\beta R I I^{+/+}$buccal tissues, expression levels of $p 21$ were not significantly altered in $\mathrm{K}_{-\mathrm{ras}^{12 D /+}}$ papillomas $(79 \% \pm 16 \%)$. In contrast, $p 21$ expression levels were reduced to $30 \% \pm 8 \%$ in TGFBRII ${ }^{-/-}$preneoplastic buccal samples, $17 \% \pm 3 \%$ in DMBA-initiated SCCs, and $17 \% \pm 5 \%$ in $\mathrm{K}_{\text {-ras }}{ }^{12 D /+} /$ TGF $\mathrm{RII} \mathrm{I}^{-/-}$tumors (Fig. $5 \mathrm{~A}$ ). Expression levels of $c$-myc were increased $3.3 \pm 0.6$-fold in DMBA-initiated TGF $R I^{-/-}$preneoplastic buccal samples, $6.0 \pm 1.3$-fold in DMBA-initiated TGFBRII $I^{-/}$ SCCs, and $4.3 \pm 2.1$-fold in $K-$ ras $^{12 D /+} / T G F \beta R I I^{-/-}$SCCs, as compared with DMBA-initiated TGF $R I^{+/+}$buccal tissues (Fig. 5B). We then examined the expression levels of cyclin D1, EGFR, and Stat3, which are not TGF- $\beta$ target genes but are commonly overexpressed/activated in human HNSCCs (Mao et al. 2004). While expression levels of these molecules did not differ significantly among DMBA-initiated TGFBRII ${ }^{+/+}$and TGF $R I^{-/-}$ buccal tissues or K-ras ${ }^{12 D}$ papillomas (Fig. 5B), expression levels of cyclinD1 were increased $8.7 \pm 2.0$-fold in DMBA-initiated TGF $R I^{-/-}$HNSCCs and $7.9 \pm 1.2$-fold in $K$-ras ${ }^{12 D /+} / T_{G F \beta R I I^{-/-}}$HNSCCs, as compared with DMBA-initiated TGF $R I^{+/+}$buccal tissues (Fig. 5B). Expression levels of $E G F R$ were increased $14.2 \pm 5.5$-fold in DMBA-initiated TGF $R I I^{-1-}$ SCCs and 5.9 \pm 2.3 -fold in K-ras ${ }^{12 D /+} /$ TGF $R I^{-/-}$SCCs, as compared with DMBAinitiated TGF $\beta R I I^{+/+}$buccal tissues (Fig. 5B). No significant alteration of Stat3 expression was observed in TGFBRII ${ }^{-1-}$ SCCs (data not shown). However, similar to human HNSCCs (Song and Grandis 2000), pStat3 ${ }^{\text {Tyr705, }}$ which is required for Stat 3 activation (Yu and Jove 2004),

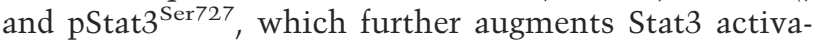
tion (Yu and Jove 2004), were both detected in DMBA-

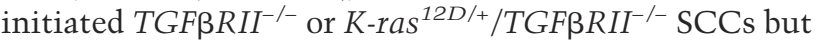
not in DMBA-initiated TGF $R I^{-/-}$and TGF $R I^{I^{+/+}}$buccal tissues (data not shown) or K-ras ${ }^{12 D /+}$ papillomas (Fig. $5 \mathrm{C})$.

TGFßRII deletion in head-and-neck epithelia resulted in increased endogenous TGFß1 and enhanced the effect of TGFß1 on tumor stroma

Human HNSCCs often exhibit increased angiogenesis and chronic inflammation (Chen et al. 1999). Similarly, TGF $\beta R_{I I^{-/-}}$preneoplastic and malignant lesions exhibited increased angiogenesis and inflammation. In DMBAinitiated TGFBRII ${ }^{-/-}$preneoplastic buccal stroma, the percentage of stromal area covered by vessels was increased by sixfold in comparison with DMBA-initiated TGF $\beta R I I^{+/+}$buccal stroma $(37 \% \pm 10 \%$ vs. $6 \% \pm 4 \%$, $p<0.01, n=5$ ) (Fig. 6A) and by fourfold in comparison with $\mathrm{K}$-ras ${ }^{12 D /+}$ papillomas $(37 \% \pm 10 \%$ vs. $9 \% \pm 6 \%$, $p<0.01, n=5$ ) (data not shown). Both K-ras ${ }^{12 D /+}$ / TGF $\beta R I I^{-/-}$and DMBA-initiated TGF $\beta R I I^{-/-}$SCCs exhibited a ninefold increase in the percentage of stromal area covered by vessels in comparison with DMBAinitiated TGFBRII $I^{+/+}$buccal stroma $(55 \% \pm 12 \%$ vs. $6 \% \pm 4 \%, p<0.01$; and $58 \% \pm 11 \%$ vs. $6 \% \pm 4 \%, p<0.01$, $n=5$ ) (Fig. 6A). Since we previously observed increased angiogenesis in preneoplastic head-and-neck tissues when TGF $\beta 1$ is overexpressed (Lu et al. 2004), we sus- 


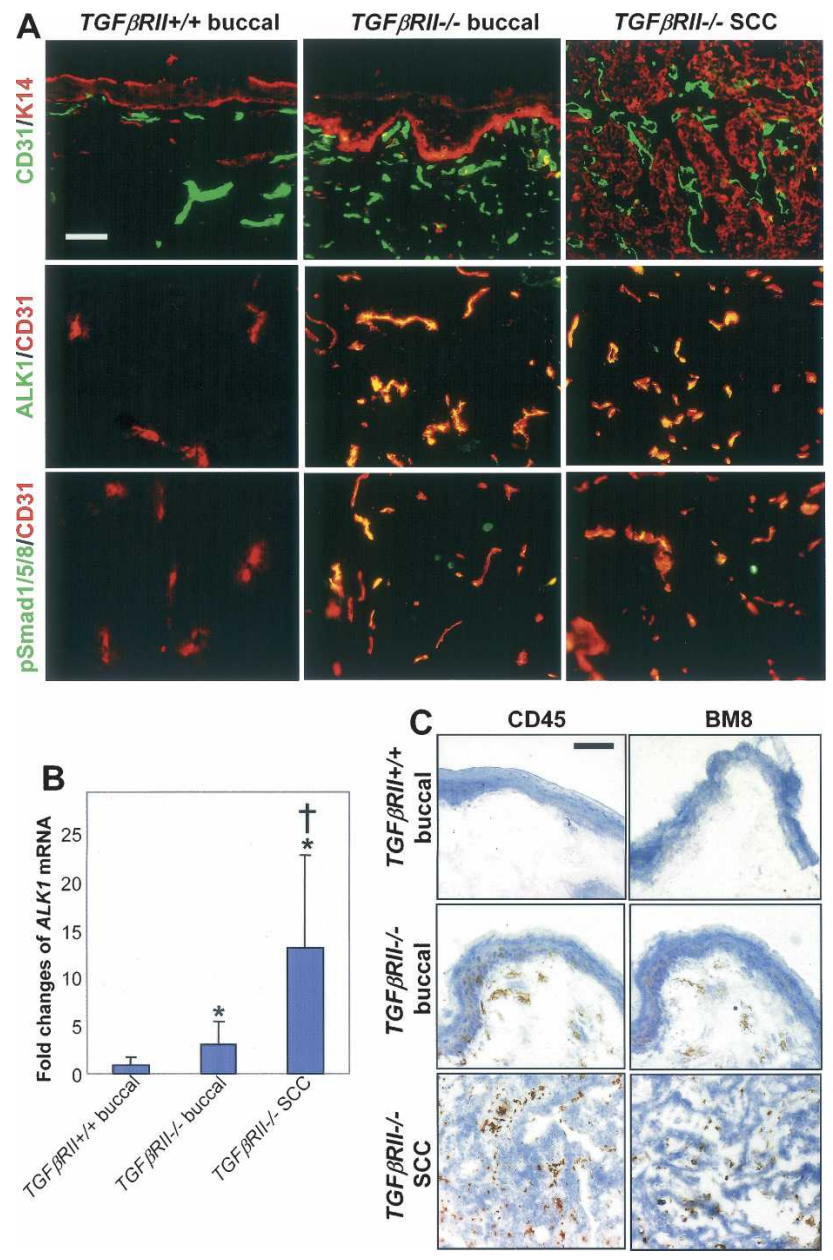

Figure 6. Increased angiogenesis and inflammation in TGF $\beta R I I^{-/-}$preneoplastic buccal mucosa and HNSCCs. (A) Immunofluorescence staining for vessels. CD31 highlights increased angiogenesis in DMBA-initiated TGF $R R^{-/-}$buccal stroma and SCCs. K14 (red), which highlights the epithelial compartment, was used as a counterstain. Staining for ALK1 and pSmad1/5/8 did not stain cells in vessels highlighted by CD31 (red) in DMBA-initiated TGF $R R I^{+/+}$buccal tissue, but stained cells of vessels in DMBA-initiated TGF $R R I I^{-/-}$buccal tissue and SCCs (yellow, indicating double fluorescence). K-ras ${ }^{12 D /+} /$ TGFBRII $^{-/-}$SCCs exhibited vessel density and ALK1 and $\mathrm{pSmad} 1 / 5 / 8$ staining patterns identical to DMBA-initiated TGF $3 R I^{-/-}$HNSCCs, whereas vessels in K-ras ${ }^{12 \mathrm{D} /+}$ papillomas were twofold higher than DMBA-initiated TGFBRII $I^{+/+}$buccal tissue but were negative for ALK1 and $\mathrm{pSmad} 1 / 5 / 8$ (not shown). (B) ALK1 mRNA levels determined by qRT-PCR. ALK1 mRNA level in DMBA-initiated TGF $\beta R I I^{+/+}$buccal tissue was set as baseline. $\left(^{*}\right) p<0.01$ in comparison with DMBA-initiated TGF $\beta R I I^{+/+}$buccal tissue; (†) $p<0.01$ in comparison with DMBA-initiated $T G F \beta R I I^{-/-}$preneoplastic buccal tissue. (C) Immunohistochemistry staining of subtypes of leukocytes. Note that total leukocytes (CD45+, brown) and macrophages (BM8+, brown) were not detectable in DMBA-initiated $T G F \beta R I I^{+/+}$buccal tissue, but were evident in the stroma and epithelia of DMBA-initiated TGF $\beta R I I^{-/-}$buccal tissue and further increased in SCCs. K-ras ${ }^{12 D /+}$ papillomas did not exhibit obvious leukocyte infiltration, but K-ras ${ }^{12 D /+} / T G F \beta R I I^{-/-}$tumors had numbers of leukocytes comparable to DMBA-initiated TGF $\beta R I I^{-/-}$tumors (not shown). Bar, $40 \mu \mathrm{m}$. pected that increased angiogenesis was a result of enhanced TGF $\beta$ signaling in tumor stroma. Supporting this, ALK1, which is the type I TGF $\beta$ receptor in endothelial cells and is elevated only during the active phase of TGF $\beta 1$-induced angiogenesis (Goumans et al. 2002),

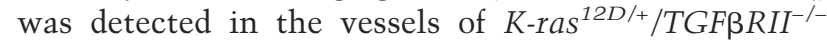
SCCs (data not shown), and in the vessels of DMBAinitiated TGFBRII ${ }^{-/}$preneoplastic buccal tissues and SCCs (Fig. 6A). In contrast, ALK1 was not detected in the blood vessels of DMBA-initiated TGFBRII $I^{++}$buccal stroma (Fig. 6A) or K-ras ${ }^{12 D /+}$ papilloma stroma (data not shown). Consistent with this change at the protein level, in comparison with $A L K 1$ expression level in DMBA-initiated TGF $\beta R I I^{+/+}$buccal tissue, ALK1 mRNA level was increased $3.1 \pm 2.3$-fold and $13.3 \pm 8.7$-fold in DMBA-initiated TGF $\beta R I I^{-/-}$preneoplastic buccal tissues and SCCs, respectively (Fig. 6B). In addition, phosphorylated Smad1/Smad5 (pSmad1/5), which mediates ALK1 signaling (Goumans et al. 2002), was not detected in the blood vessels of DMBA-initiated TGFBRII $I^{++}$buccal stroma (Fig. 6A) or K-ras ${ }^{12 D /+}$ papilloma stroma (data not shown), but was detected in the vessels of $K$ $\mathrm{ras}^{12 D /+} / \mathrm{TGF} \mathrm{RII}^{-/-}$SCCs (data not shown), and in the vessels of DMBA-initiated TGFBRII ${ }^{-/}$preneoplastic buccal tissues and SCCs (Fig. 6A). With respect to inflammation, CD45 immunostaining, which highlights leukocytes, revealed numerous infiltrated leukocytes in K-ras ${ }^{12 D /+} / T_{G F \beta R I I^{-/-}}$(data not shown) or DMBA-initiated SCCs (Fig. 6C), but not in $\mathrm{K}_{\text {-ras }}{ }^{12 D /+}$ papillomas (data not shown). To determine whether this is a direct effect of TGF $\beta$ RII loss, we examined DMBA-initiated buccal tissues. CD45-positive cells were not detected in DMBA-initiated TGF $R I I^{+/+}$buccal tissue, but were numerous in DMBA-initiated TGFBRII-/- preneoplastic buccal tissue (Fig. 6C). Most of the leukocytes were macrophages as evidenced by positive staining using the BM8 antibody (Fig. 6C) and granulocytes that were detected using the Ly-6G antibody (data not shown). We also examined inflammatory cytokines and chemokines that have been shown to be elevated by TGF $\beta 1$ and play a role in angiogenesis ( $\mathrm{Li}$ et al. 2004; Chen et al. 2005; Orimo et al. 2005). In comparison with DMBA-initiated TGF $\beta R I I^{+/+}$buccal tissues, expression levels of interleukin $1 \beta(I L-1 \beta)$ and macrophage inflammatory protein 2 (MIP-2), a murine counterpart of human $I L-8$, were not significantly increased in $K$ - ras $^{12 D /+}$ papillomas, but increased 10.2 \pm 4.4-fold and $4.5 \pm 1.6$-fold, respectively, in DMBA-initiated TGF $\beta R I I^{-/-}$preneoplastic buccal tissues. $I L-1 \beta$ and $M I P-2$ further increased $25.0 \pm 5.4$-fold and $29.3 \pm 9.2$-fold, respectively, in DMBA-initiated TGFBRII ${ }^{-1-}$ HNSCCs, and 19.4 \pm 9.3-fold and 8.9 \pm 7.0fold, respectively, in $\mathrm{K}-\mathrm{ras}^{12 D /+} / \mathrm{TGF} \mathrm{RII} \mathrm{I}^{-/-}$HNSCCs (Fig. 7A). Similarly, in comparison with DMBA-initiated TGF $\beta R I I^{+/+}$buccal tissues, expression levels of stromalderived factor $(S D F)-1$ and its receptor, CXCR4, were not altered in $\mathrm{K}$-ras ${ }^{12 D /+}$ papillomas, but increased $2.3 \pm 0.8$-fold and $2.9 \pm 0.6$-fold, respectively, in DMBAinitiated TGFBRII ${ }^{-/-}$preneoplastic buccal tissues. SDF-1 and CXCR4 were further increased 7.2 \pm 3.9 -fold and $6.8 \pm 2.3$-fold, respectively, in DMBA-initiated TGFßRII ${ }^{-/}$ 
Figure 7. Increased inflammatory cytokines/ chemokines and fibroblast activation in TGF $R R_{I} I^{-/}$preneoplastic tissues and HNSCCs correlated with increased endogenous TGF $\beta 1$ expression. (A) Relative expression levels of TGF 1 target molecules related to inflammation as quantified by qRT-PCR. Each group contained six samples. Expression levels of individual molecules in DMBA-initiated $T G F \beta R I I^{+/+}$buccal tissue were set to the value of 1 arbitrary unit. (B) Increased TGF 1 mRNA expression levels in $T G F \beta R I I^{-1-}$ preneoplastic tissues and tumors. $(A-B)\left(^{*}\right) p<0.01$ in comparison with DMBAinitiated TGFßRII ${ }^{++}$buccal tissue; (†) $p<0.01$ in comparison with DMBA-initiated TGF $\beta R I I^{-/-}$preneoplastic buccal tissue. (C) Levels of TGF 1 , tenascin $C$, and CTGF transcripts detected by qRT-PCR using RNA isolated from LCM captured cells of DMBA-initiated head-and-neck tissues and tumors. Results from four samples in each group are presented. Expression levels of individual molecules in DMBA-initiated preneoplastic $T G F \beta R I I^{-/-}$buccal epithelial cells were set to the value of 1 arbitrary unit. $\left(^{\star}\right) p<0.01$ in

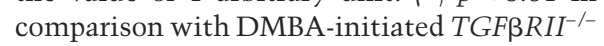
epithelial cells; $(+) p<0.01$ in comparison with those in stromal cells of DMBA-initiated TGF $\beta R I I^{-/-}$SCCs. (D) Immunohistochemistry staining of $\alpha$-SMA. Note that $\alpha$-SMA-positive cells were not detected in DMBA-initiated TGF $\beta R I^{I^{++}}$buccal stroma or K-ras ${ }^{12 D /+}$ papillomas other than in vessel walls, but

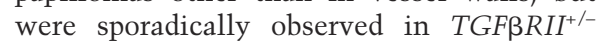
buccal stroma (arrows), and were numerous in the stroma of DMBA-initiated TGFBRII ${ }^{-/-}$ SCC or K-ras ${ }^{12 D /+} / T G F \beta R I I^{-/-}$SCC. The light-brown staining in the epithelium and stroma of each section in $D$ represents nonspecific background staining. Bar, $40 \mu \mathrm{m}$.
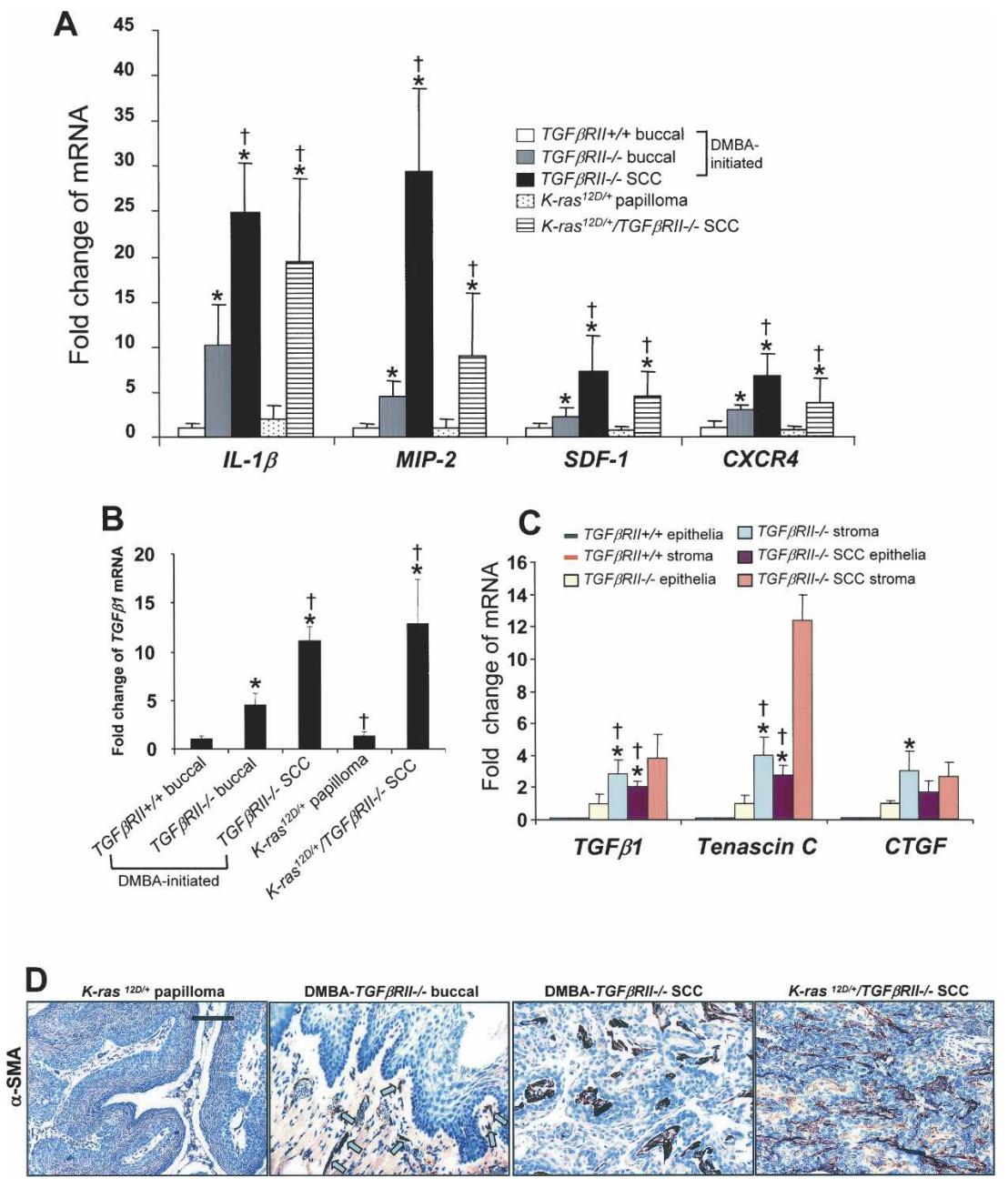

HNSCCs, and $4.4 \pm 2.9$-fold and $3.7 \pm 2.9$-fold, respectively, in $\mathrm{K}_{\text {-ras }}{ }^{12 D /+} / \mathrm{TGF} \beta \mathrm{RII}^{-/-}$tumors (Fig. 7A). To determine if the above alterations correlate with endogenous TGF $\beta 1$ levels, we examined expression levels of TGF $\beta 1$. In comparison with wild-type buccal tissues, expression levels of TGF $\beta 1$ were not changed in K-ras ${ }^{12 D /+}$ papillomas. However, TGF $\beta 1$ expression levels were increased $4.3 \pm 1.2$-fold, $10.6 \pm 1.4$-fold, and $12.2 \pm 4.5$-fold in DMBA-initiated TGF $R I^{-/-}$buccal tissues, SCCs, and $K-$ ras $^{12 D /+} /$ TGF $\beta R I I^{-/-}$SCCs, respectively (Fig. 7B). We then examined sources of TGF 1 overexpression using laser capture microdissection (LCM)-dissected epithelial and stromal cells from DMBA-initiated TGF $\beta R I I^{-1-}$ buccal tissues and tumors. The levels of TGF 1 transcripts were too low to be detected in LCMcaptured epithelial and stromal cells of DMBA-initiated TGF $\beta R I I^{+/+}$buccal tissues. However, in response to TGF $\beta$ RII deletion, both epithelia and stroma exhibited increased TGF 1 expression, but the increase was more significant in the stroma (Fig. 7C). Concomitantly, tenascin $C$ and connective tissue growth factor (CTGF), which are TGF $\beta 1$ target genes primarily expressed in stromal cells and promote tumor invasion (Kang et al. 2003; Jinnin et al. 2004), exhibited a significant increase in the stromal cells with mild de novo epithelial expres-

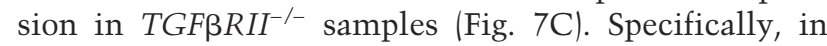
comparison with epithelial cells of DMBA-initiated TGF $R I I^{-/-}$preneoplastic buccal tissues, expression levels of TGF 1 , tenascin $C$, and CTGF were elevated by $2.8 \pm 0.9$-fold, $4.0 \pm 1.1$-fold, and $3.0 \pm 1.2$-fold, respectively, in buccal stromal cells, and $4 \pm 1.5$-fold, $12.4 \pm 1.5$-fold, and $3.0 \pm 0.9$-fold, respectively, in tumor stromal cells (Fig. 7C). The levels of TGF 1 and tenascin $C$ in DMBA-initiated TGF $R I^{-/}$HNSCC epithelial cells were also elevated $2.0 \pm 0.4$-fold and $2.7 \pm 0.7$-fold, respectively, in comparison with epithelial cells of DMBA-initiated TGF RRII ${ }^{-/-}$preneoplastic buccal tissues (Fig. 7C). Consistent with these molecular alterations, immunostaining revealed that myofibroblastswhich express $\alpha$-smooth muscle actin ( $\alpha$-SMA), are often induced by TGFß1 (Lewis et al. 2004), and play an important role in tumor progression (Orimo et al. 2005) - 
were not detected in the stroma of DMBA-initiated TGF $\beta R I I^{+/+}$buccal or $\mathrm{K}-\mathrm{ras}^{12 D /+}$ papillomas (Fig. 7C), but appeared sporadically in DMBA-initiated TGFBRII ${ }^{-/-}$ preneoplastic buccal stroma and numerous in the stroma of DMBA-initiated TGFBRII $I^{-/-}$and $\mathrm{K}_{-\mathrm{ras}}{ }^{12 \mathrm{D} / \mathrm{+}} /$ TGFßRII-l- SCCs (Fig. 7D).

\section{Discussion}

Previous reports have revealed low frequencies of ras mutations in HNSCC lesions of patients in Western countries (Anderson et al. 1994; Hardisson 2003; Weber et al. 2003). Here, we show that Ras activation, in combination with mutation and wild-type ras overexpression, is significantly higher in human HNSCCs than previously appreciated. The occurrence of ras overexpression at a relatively early stage during HNSCC development in humans and the early onset of papilloma formation in K-ras mutant murine head-and-neck epithelia indicate an initiation role for Ras activation in HNSCC development. However, Ras activation alone is not sufficient to induce invasive HNSCC, which explains why previous observations did not find a correlation between Ras activation and HNSCC prognosis (McDonald et al. 1994). Nevertheless, once TGFßRII is lost, Ras-activated cells rapidly progress to invasive HNSCC in mice. Although TGF $\beta$ RII has been shown to have a tumor-suppressive effect in several tissues (Reiss 1999; Prime et al. 2004), its potency and stage-specific effect vary among different tissues (Biswas et al. 2004; Forrester et al. 2005). Considering that TGF $\beta$ RII loss was not detected in preneoplastic lesions of the human headand-neck tissue adjacent to HNSCCs, and that TGFßRII loss in mouse head-and-neck epithelia did not spontaneously result in obvious pathological alterations, TGFßRII loss seems not to function as an initiation event for HNSCC carcinogenesis. However, TGFßRII loss appears to play a causal role in HNSCC progression. Expression of TGF $\beta 1$ target genes that are related to growth regulation (i.e., $p 15, p 21$, and $c$-myc) was misregulated in preneoplastic and SCC lesions with $T G F \beta R I I$ deletion. In contrast, even though K-ras activation-induced hyperproliferation was sufficient to induce papilloma formation, expression levels of $p 15, p 21$, and $c$-myc were not significantly altered, presumably due to intact TGF $\beta$ signaling in these papillomas. Thus, abrogation of TGF $\beta$-mediated growth inhibition may play a role in field cancerization for HNSCC. Consequently, TGFßRII loss allowed further accumulation of multiple molecular alterations that have been documented in human HNSCCs, which, again, did not occur in $\mathrm{K}_{-} \mathrm{ras}^{12 \mathrm{D} /+}$ papillomas. Among them, overexpression of EGFR is observed in $80 \%-90 \%$ of human HNSCCs and correlates with poor clinical outcome (Grandis and Sok 2004). EGFR activation can also activate Stat3, which is activated in $>90 \%$ of human HNSCCs (Song and Grandis 2000). Stat 3 has been shown to be responsible for cyclin D1 overexpression in HNSCCs (Masuda et al. 2002), which is seen in $\sim 40 \%$ of human HNSCC tumors (Michalides et al. 1997). Cyclin D1 overexpression in trans- genic mice resulted in dysplastic oral lesions, and with the loss of one p53 allele, $60 \%$ of these mice developed HNSCCs (Opitz et al. 2002). Therefore, the step-wise accumulation of multiple insults that occurred in TGF $\beta R I I^{-/-}$lesions appeared to allow initiated cells to progress to malignancy via hyperproliferation accompanied by decreased differentiation. In contrast, K-ras ${ }^{12 D /+}$ papillomas with wild-type TGFBRII, which did not exhibit accumulation of these additional molecular alterations, still possessed a relatively normal differentiation phenotype.

TGF $\beta 1$ has tumor-suppressive and promotion effects at early and late stages of carcinogenesis, respectively, both of which should be mediated by TGFßRII (Reiss 1999; Wang 2001; Prime et al. 2004). Thus, rapid tumor invasion in TGF $\beta R^{-/} I^{-}$HNSCCs was somehow unexpected. The accumulated oncogenic events in tumor epithelia (discussed above) likely contributed to the enhanced tumor progression. Additionally, we observed increased endogenous TGF $\beta 1$ levels in TGF $R I^{-/-}$tissues and tumors, but not in $\mathrm{K}$-ras ${ }^{12 D /+}$ papillomas, indicating a negative feedback from the host tissue following epithelial TGF $\beta$ RII loss. Since TGF $\beta$ RII was absent from the epithelia, increased TGF $\beta 1$ could not exert a tumorsuppressive effect. However, TGFßRII remained intact in tumor stroma. Therefore, increased endogenous TGF $\beta 1$ (either secreted from epithelia or directly from the stroma) would enhance TGF $\beta 1$ signaling in tumor stroma. TGF $\beta 1$ has been shown to have a direct effect on angiogenesis (Goumans et al. 2002) and myofibroblast formation (Lewis et al. 2004), both of which are evidenced in TGF $R R^{-/-}$lesions. Consistent with the documented immune-suppressive effect but a potent chemotactic effect on macrophages and neutrophils of TGF $\beta 1$ (Letterio and Roberts 1998; Wahl 1999), TGFßRII'-head-and-neck lesions exhibited increased macrophages and neutrophils but not lymphocytes. Furthermore, elevated TGF $\beta 1$ and increased inflammation, angiogenesis, and myofibroblast formation occurred in TGF $\beta R I I^{-/-}$lesions even prior to HNSCC formation, indicating that these events were not tumor stage-specific events, but rather suggested the direct effect of TGF $\beta 1$ on nonepithelial cells. Once TGF $\beta 1$ initiated these processes, infiltrated leukocytes, activated fibroblasts, and tumor epithelial cells would subsequently produce inflammatory cytokines/chemokines and angiogenesis factors. This explains why our transgenic SCC lesions exhibited such a marked exacerbation of the above pathological processes. Therefore, TGF $\beta R I I^{-/-}$SCCs, which already have a growth advantage in tumor epithelia, can progress more rapidly in such a microenvironment.

In summary, we report the first mouse model to develop HNSCCs with complete penetrance. Since TGFBRII loss can rapidly promote malignant progression, this mouse model will be a useful tool for screening genetic alterations that play an initiation role in HNSCC. Additionally, this mouse model will provide a unique tool for testing targeted therapies. Considering that most of the aggressive HNSCC cells lose TGF $\beta 1$ mediated growth inhibition via loss of TGF $\beta$ RII or other 
molecular alterations, inhibition of the remaining TGF $\beta 1$ effect on tumor stroma in combination with the current concept of targeted therapy to cancer epitheliae.g., blocking Ras/EGFR/Stat signaling — may provide an effective therapy for HNSCC.

\section{Materials and methods}

\section{Patients}

HNSCCs and case-matched adjacent tissue samples were surgically resected between the years 2000 and 2005 from consenting patients at the Department of Otolaryngology, Oregon Health and Science University, under an Institutional Review Boardapproved protocol. Tissues examined in this study included 14 tongue SCCs, eight oral SCCs, four pharyngeal SCCs, six larynx SCCs, and case-matched tissues adjacent to tumors. Seven normal oropharyngeal samples from sleep apnea patients were used as normal controls.

Generation of mice with head-and-neck-specific TGFßRII deletion and $\mathrm{K}$-ras ${ }^{G 12 D}$ activation

All animal experiments were performed using protocols approved by the Institutional Animal Care and Use Committees at the Oregon Health and Science University. The inducible head-and-neck specific knockout/activation system consists of two mouse lines: K5.CrePR1 mice (in which the Cre recombinase can be activated in head-and-neck epithelia by RU486 [Caulin et al. 2004]) and TGF $R I I^{f / f}$ mice (in which the TGF $R R I I$ gene is floxed [Forrester et al. 2005]) or the LSL-K-ras ${ }^{G 12 D}$ mice (in which a floxed stop sequence is inserted upstream of the K-ras coding region [Jackson et al. 2001]). These mouse lines were cross-bred to generate compound mice that allow homozygous or heterozygous TGF $\beta R I I$ deletion with or without K-ras ${ }^{12 D /+}$ activation. Littermates were genotyped at $3 \mathrm{wk}$ of age and grouped based on genotypes for the experiments. RU486 (100 $\mu \mathrm{L}$ of $0.2 \mu \mathrm{g} / \mu \mathrm{L}$ in sesame oil) was applied in the oral cavity of 4-wk-old bigenic or trigenic mice daily for five consecutive days to induce homozygous or heterozygous deletion of the TGF $\beta R I I$ gene with or without concurrent $\mathrm{K}$-ras $\mathrm{s}^{12 \mathrm{D} /+}$ activation. Monogenic littermates were also treated with the same RU486 regimen as controls. For DMBA-initiation, a single dose of $20 \mu \mathrm{g}$ of DMBA (Sigma; dissolved in $50 \mu \mathrm{L}$ of sesame oil) was applied orally to each group of mice $10 \mathrm{~d}$ after the last RU486 treatment. The general condition of the mice was checked at least once per week prior to the development of visible tumors. Mice with oral tumors were given soft food and monitored daily. Tumor-bearing mice were euthanized when oral tumors became ulcerated, or at first sign of deteriorating health conditions or pain resulting from tumors (e.g., huddled posture, vocalization, hypothermia, or $\geq 20 \%$ weight loss). Paired TGF $\beta R I I^{+/+}$ littermates treated with DMBA were euthanized at the same time, and the corresponding tissue samples were dissected as controls. Necropsy was performed on each euthanized mouse to identify primary tumors and distant metastases. To dissect early preneoplastic lesions, mice with each genotype were euthanized 4 wk after DMBA initiation, and head-and-neck tissue including the buccal tissue, tongue, esophagus, and forestomach were dissected.

\section{Histology and immunostaining}

Samples were fixed in $10 \%$ neutral buffered formalin, embedded, sectioned, and stained with H\&E as we have previously described (Lu et al. 2004). Tumor types were determined by at least two independent pathologists based on the criteria described previously (Han et al. 2005). Immunohistochemical staining was performed on paraffin-embedded sections using an antibody that recognizes both K-ras and H-ras (Abcam), a TGFßRII antibody (Santa Cruz Biotechnology), pSmad2,

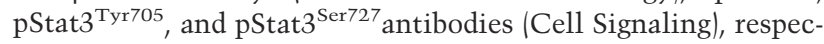
tively, as we have previously described (McDonald et al. 1994; Han et al. 2005). Immunohistochemical staining of leukocyte markers was performed on frozen sections using primary antibodies to CD45 (BD Biosciences) and the BM8 antibody (BMA Biomedicals) as previously described (Li et al. 2004). Sections were counterstained with hematoxylin. A double-blind evaluation of TGFßRII staining in human HNSCC samples was performed by two investigators using the methods described previously (Han et al. 2005). Double-stain immunofluorescence was performed as we have described previously (Li et al. 2004). The primary antibodies included Keratins K1, K13, and K18 (RDI), and CD31 (BD Biosciences). A guinea pig antiserum against mouse keratin 14 (RDI), which highlights the epithelial compartment of head-and-neck tissues, was used as a counterstain. The sections were incubated with Alexa 488-conjugated secondary antibodies (Molecular Probes) and an Alexa 594-conjugated (red) anti-guinea pig antibody (Molecular Probes). For ALK1 (R\&D Systems) and pSmad1/5/8 (Cell Signaling) double staining, CD31 was used as a counterstain as previously described (Lu et al. 2004). Quantitation of blood vessels was performed using the MetaMorph software (Universal Imaging Corporation).

\section{Protein analysis}

Western blot was performed using a specific TGFßRII antibody (Santa Cruz Biotechnology) and the ECL-plus chemiluminescent detection system (Amersham).

\section{RNA isolation, LCM, and $q R T-P C R$}

Total RNA was isolated using Trizol (Invitrogen) and further purified using a Qiagen RNeasy Mini kit as previously described (Li et al. 2004). Five micrograms of RNA from each sample was treated with DNase (Ambion) and then subjected to an RT reaction using AMV reverse transcriptase. For LCM, OCT frozen sections $(5 \mu \mathrm{m})$ were stained with the HistoGene LCM staining kit (Arcturus). The PixCell II LCM system (Arcturus) was used to capture normal keratinocytes, normal stromal cells, tumor epithelial cells, and tumor stromal cells. RNA was isolated from the LCM-captured cells using the PicoPure RNA isolation kit (Arcturus), and cDNA was synthesized using the Sensiscript RT kit (Qiagen). cDNA products were subjected to qRT-PCR using TaqMan Assays-on-Demand probes (Applied Biosystems). An $18 \mathrm{~S}$ RNA probe was used as an internal control. Each sample was examined in triplicate. The relative RNA expression levels were determined by normalizing with the $18 \mathrm{~S}$ transcripts, the values of which were calculated using the comparative $C_{T}$ method.

\section{Statistical analysis}

Statistical differences between two groups of data were analyzed using the Student's $t$-test. The data are presented as mean \pm SD (standard deviation) with the exception of the data in Figure 1, which are presented as mean \pm SE (standard error).

\section{Acknowledgments}

We thank Dr. Tyler Jacks for providing $L S L-K-$ ras $^{G 12 D}$ mice, Dr. Harold Moses for providing TGF $\beta R I I^{f / f}$ mice, the Molecular Pro- 
filing Resource of the Departments of Otolaryngology and Dermatology, the surgeons in Otolaryngology for collecting HNSCC samples, and Drs. John Scott and Hua Lu for comments on the manuscript. This research was supported by NIH grants DE015953, CA87849, CA105491, and CA79998 to X.J.W. H.H. is a recipient of the NIH training grant.

\section{References}

Anderson, J.A., Irish, J.C., McLachlin, C.M., and Ngan, B.Y. 1994. H-ras oncogene mutation and human papillomavirus infection in oral carcinomas. Arch. Otolaryngol. Head Neck Surg. 120: 755-760.

Arin, M.J., Longley, M.A., Wang, X.J., and Roop, D.R. 2001. Focal activation of a mutant allele defines the role of stem cells in mosaic skin disorders. J. Cell Biol. 152: 645-649.

Biswas, S., Chytil, A., Washington, K., Romero-Gallo, J., Gorska, A.E., Wirth, P.S., Gautam, S., Moses, H.L., and Grady, W.M. 2004. Transforming growth factor $\beta$ receptor type II inactivation promotes the establishment and progression of colon cancer. Cancer Res. 64: 4687-4692.

Bloor, B.K., Su, L., Shirlaw, P.J., and Morgan, P.R. 1998. Gene expression of differentiation-specific keratins (4/13 and $1 / 10)$ in normal human buccal mucosa. Lab. Invest. 78: 787-795.

Caulin, C., Nguyen, T., Longley, M.A., Zhou, Z., Wang, X.J., and Roop, D.R. 2004. Inducible activation of oncogenic K-ras results in tumor formation in the oral cavity. Cancer Res. 64: 5054-5058.

Chen, Z., Malhotra, P.S., Thomas, G.R., Ondrey, F.G., Duffey, D.C., Smith, C.W., Enamorado, I., Yeh, N.T., Kroog, G.S., Rudy, S., et al. 1999. Expression of proinflammatory and proangiogenic cytokines in patients with head and neck cancer. Clin. Cancer Res. 5: 1369-1379.

Chen, S., Tuttle, D.L., Oshier, J.T., Knot, H.J., Streit, W.J., Goodenow, M.M., and Harrison, J.K. 2005. Transforming growth factor- $\beta 1$ increases CXCR4 expression, stromal-derived factor- $1 \alpha$-stimulated signalling and human immunodeficiency virus-1 entry in human monocyte-derived macrophages. Immunology 114: 565-574.

Forastiere, A.A., Goepfert, H., Maor, M., Pajak, T.F., Weber, R., Morrison, W., Glisson, B., Trotti, A., Ridge, J.A., Chao, C., et al. 2003. Concurrent chemotherapy and radiotherapy for organ preservation in advanced laryngeal cancer. N. Engl. J. Med. 349: 2091-2098.

Forrester, E., Chytil, A., Bierie, B., Aakre, M., Gorska, A.E., Sharif-Afshar, A.R., Muller, W.J., and Moses, H.L. 2005. Effect of conditional knockout of the type II TGF- $\beta$ receptor gene in mammary epithelia on mammary gland development and polyomavirus middle $\mathrm{T}$ antigen induced tumor formation and metastasis. Cancer Res. 65: 2296-2302.

Fukai, Y., Fukuchi, M., Masuda, N., Osawa, H., Kato, H., Nakajima, T., and Kuwano, H. 2003. Reduced expression of transforming growth factor- $\beta$ receptors is an unfavorable prognostic factor in human esophageal squamous cell carcinoma. Int. J. Cancer 104: 161-166.

Garrigue-Antar, L., Munoz-Antonia, T., Antonia, S.J., Gesmonde, J., Vellucci, V.F., and Reiss, M. 1995. Missense mutations of the transforming growth factor $\beta$ type II receptor in human head and neck squamous carcinoma cells. Cancer Res. 55: 3982-3987.

Goumans, M.J., Valdimarsdottir, G., Itoh, S., Rosendahl, A., Sideras, P., and ten Dijke, P. 2002. Balancing the activation state of the endothelium via two distinct TGF- $\beta$ type I receptors. EMBO J. 21: 1743-1753.

Grandis, J.R. and Sok, J.C. 2004. Signaling through the epidermal growth factor receptor during the development of ma- lignancy. Pharmacol. Ther. 102: 37-46.

Han, G., Lu, S.L., Li, A.G., He, W., Corless, C.L., Kulesz-Martin, M., and Wang, X.J. 2005. Distinct mechanisms of TGF- $\beta 1$ mediated epithelial-to-mesenchymal transition and metastasis during skin carcinogenesis. J. Clin. Invest. 115: 17141723.

Hanahan, D. and Weinberg, R.A. 2000. The hallmarks of cancer. Cell 100: 57-70.

Hardisson, D. 2003. Molecular pathogenesis of head and neck squamous cell carcinoma. Eur. Arch. Otorhinolaryngol. 260: 502-508.

Hoa, M., Davis, S.L., Ames, S.J., and Spanjaard, R.A. 2002. Amplification of wild-type K-ras promotes growth of head and neck squamous cell carcinoma. Cancer Res. 62: 7154-7156.

Jackson, E.L., Willis, N., Mercer, K., Bronson, R.T., Crowley, D., Montoya, R., Jacks, T., and Tuveson, D.A. 2001. Analysis of lung tumor initiation and progression using conditional expression of oncogenic K-ras. Genes \& Dev. 15: 3243-3248.

Jemal, A., Tiwari, R.C., Murray, T., Ghafoor, A., Samuels, A., Ward, E., Feuer, E.J., and Thun, M.J. 2004. Cancer statistics, 2004. CA Cancer J. Clin. 54: 8-29.

Jinnin, M., Ihn, H., Asano, Y., Yamane, K., Trojanowska, M., and Tamaki, K. 2004. Tenascin-C upregulation by transforming growth factor- $\beta$ in human dermal fibroblasts involves Smad3, Sp1, and Ets1. Oncogene 23: 1656-1667.

Kang, Y., Siegel, P.M., Shu, W., Drobnjak, M., Kakonen, S.M., Cordon-Cardo, C., Guise, T.A., and Massague, J. 2003. A multigenic program mediating breast cancer metastasis to bone. Cancer Cell 3: 537-549.

Letterio, J.J. and Roberts, A.B. 1998. Regulation of immune responses by TGF- $\beta$. Annu. Rev. Immunol. 16: 137-161.

Lewis, M.P., Lygoe, K.A., Nystrom, M.L., Anderson, W.P., Speight, P.M., Marshall, J.F., and Thomas, G.J. 2004. Tumour-derived TGF- $\beta 1$ modulates myofibroblast differentiation and promotes HGF/SF-dependent invasion of squamous carcinoma cells. Br. J. Cancer 90: 822-832.

Li, A.G., Wang, D., Feng, X.H., and Wang, X.J. 2004. Latent TGF $\beta 1$ overexpression in keratinocytes results in a severe psoriasis-like skin disorder. EMBO J. 23: 1770-1781.

Lu, S.L., Reh, D., Li, A.G., Woods, J., Corless, C.L., KuleszMartin, M., and Wang, X.J. 2004. Overexpression of transforming growth factor $\beta 1$ in head and neck epithelia results in inflammation, angiogenesis, and epithelial hyperproliferation. Cancer Res. 64: 4405-4410.

Mao, L., Hong, W.K., and Papadimitrakopoulou, V.A. 2004. Focus on head and neck cancer. Cancer Cell 5: 311-316.

Massague, J. 2004. G1 cell-cycle control and cancer. Nature 432: 298-306.

Masuda, M., Suzui, M., Yasumatu, R., Nakashima, T., Kuratomi, Y., Azuma, K., Tomita, K., Komiyama, S., and Weinstein, I.B. 2002. Constitutive activation of signal transducers and activators of transcription 3 correlates with cyclin D1 overexpression and may provide a novel prognostic marker in head and neck squamous cell carcinoma. Cancer Res. 62: 3351-3355.

McDonald, J.S., Jones, H., Pavelic, Z.P., Pavelic, L.J., Stambrook, P.J., and Gluckman, J.L. 1994. Immunohistochemical detection of the H-ras, K-ras, and N-ras oncogenes in squamous cell carcinoma of the head and neck. I. Oral Pathol. Med. 23: 342-346.

Michalides, R.J., van Veelen, N.M., Kristel, P.M., Hart, A.A., Loftus, B.M., Hilgers, F.J., and Balm, A.J. 1997. Overexpression of cyclin D1 indicates a poor prognosis in squamous cell carcinoma of the head and neck. Arch. Otolaryngol. Head Neck Surg. 123: 497-502.

Ogden, G.R., Lane, E.B., Hopwood, D.V., and Chisholm, D.M. 
Lu et al.

1993. Evidence for field change in oral cancer based on cytokeratin expression. Br. J. Cancer 67: 1324-1330.

Opitz, O.G., Harada, H., Suliman, Y., Rhoades, B., Sharpless, N.E., Kent, R., Kopelovich, L., Nakagawa, H., and Rustgi, A.K. 2002. A mouse model of human oral-esophageal cancer. J. Clin. Invest. 110: 761-769.

Orimo, A., Gupta, P.B., Sgroi, D.C., Arenzana-Seisdedos, F., Delaunay, T., Naeem, R., Carey, V.J., Richardson, A.L., and Weinberg, R.A. 2005. Stromal fibroblasts present in invasive human breast carcinomas promote tumor growth and angiogenesis through elevated SDF-1/CXCL12 secretion. Cell 121: 335-348.

Potten, C.S., Saffhill, R., and Maibach, H.I. 1987. Measurement of the transit time for cells through the epidermis and stratum corneum of the mouse and guinea-pig. Cell Tissue Kinet. 20: 461-472.

Prime, S.S., Davies, M., Pring, M., and Paterson, I.C. 2004. The role of TGF- $\beta$ in epithelial malignancy and its relevance to the pathogenesis of oral cancer (part II). Crit. Rev. Oral Biol. Med. 15: 337-347.

Reiss, M. 1999. TGF- $\beta$ and cancer. Microbes Infect. 1: 1327-1347.

Saranath, D., Chang, S.E., Bhoite, L.T., Panchal, R.G., Kerr, I.B., Mehta, A.R., Johnson, N.W., and Deo, M.G. 1991. High frequency mutation in codons 12 and 61 of H-ras oncogene in chewing tobacco-related human oral carcinoma in India. $\mathrm{Br}$. J. Cancer 63: 573-578.

Siegel, P.M., Shu, W., Cardiff, R.D., Muller, W.J., and Massague, J. 2003. Transforming growth factor $\beta$ signaling impairs Neuinduced mammary tumorigenesis while promoting pulmonary metastasis. Proc. Natl. Acad. Sci. 100: 8430-8435.

Song, J.I. and Grandis, J.R. 2000. STAT signaling in head and neck cancer. Oncogene 19: 2489-2495.

Tateishi, M., Kusaba, I., Masuda, H., Tanaka, T., Matsumata, T., and Sugimachi, K. 2000. The progression of invasiveness regarding the role of transforming growth factor $\beta$ receptor type II in gastric cancer. Eur. J. Surg. Oncol. 26: 377-380.

Vitale-Cross, L., Amornphimoltham, P., Fisher, G., Molinolo, A.A., and Gutkind, J.S. 2004. Conditional expression of K-ras in an epithelial compartment that includes the stem cells is sufficient to promote squamous cell carcinogenesis. Cancer Res. 64: 8804-8807.

Wahl, S.M. 1999. TGF- $\beta$ in the evolution and resolution of inflammatory and immune processes. Introduction. Microbes Infect. 1: 1247-1249.

Wang, X.J. 2001. Role of TGF $\beta$ signaling in skin carcinogenesis. Microsc. Res. Tech. 52: 420-429.

Wang, D., Song, H., Evans, J.A., Lang, J.C., Schuller, D.E., and Weghorst, C.M. 1997. Mutation and downregulation of the transforming growth factor $\beta$ type II receptor gene in primary squamous cell carcinomas of the head and neck. Carcinogenesis 18: 2285-2290.

Watanabe, T., Wu, T.T., Catalano, P.J., Ueki, T., Satriano, R., Haller, D.G., Benson III, A.B., and Hamilton, S.R. 2001. Molecular predictors of survival after adjuvant chemotherapy for colon cancer. N. Engl. J. Med. 344: 1196-1206.

Weber, A., Langhanki, L., Sommerer, F., Markwarth, A., Wittekind, C., and Tannapfel, A. 2003. Mutations of the BRAF gene in squamous cell carcinoma of the head and neck. Oncogene 22: 4757-4759.

Yang, Y.A., Dukhanina, O., Tang, B., Mamura, M., Letterio, J.J., MacGregor, J., Patel, S.C., Khozin, S., Liu, Z.Y., Green, J., et al. 2002. Lifetime exposure to a soluble TGF- $\beta$ antagonist protects mice against metastasis without adverse side effects. J. Clin. Invest. 109: 1607-1615.

$\mathrm{Yu}, \mathrm{H}$. and Jove, R. 2004. The STATs of cancer-New molecular targets come of age. Nat. Rev. Cancer 4: 97-105. 


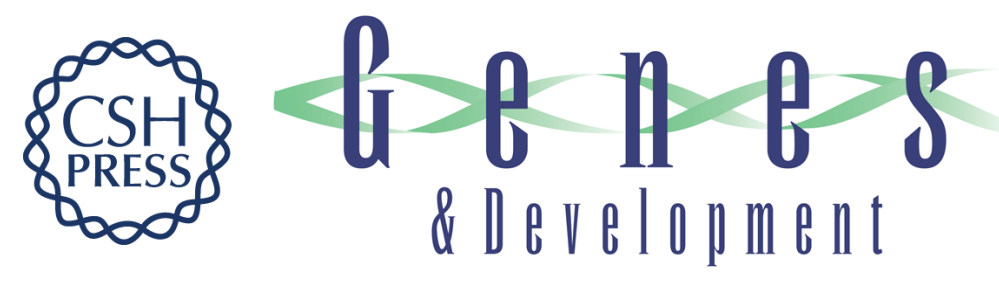

\section{Loss of transforming growth factor- $\beta$ type II receptor promotes metastatic head-and-neck squamous cell carcinoma}

Shi-Long Lu, Heather Herrington, Douglas Reh, et al.

Genes Dev. 2006, 20:

Access the most recent version at doi:10.1101/gad.1413306

Supplemental http://genesdev.cshlp.org/content/suppl/2006/05/15/20.10.1331.DC1
Material

References This article cites 48 articles, 14 of which can be accessed free at:

http://genesdev.cshlp.org/content/20/10/1331.full.html\#ref-list-1

License

Email Alerting Receive free email alerts when new articles cite this article - sign up in the box at the top

Service

right corner of the article or click here.

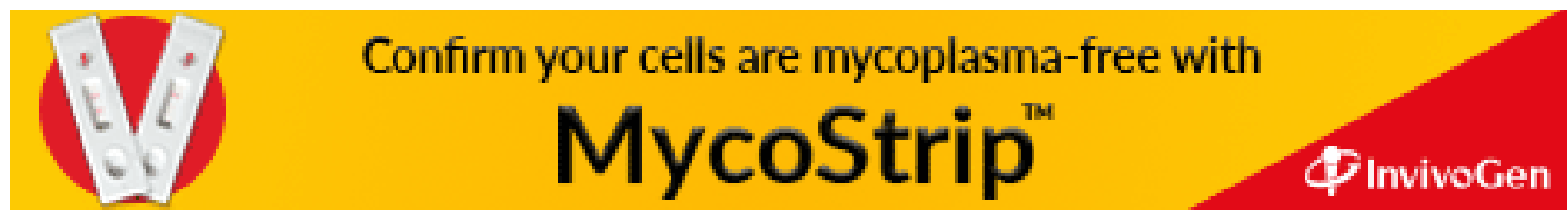

